\title{
The future of auditing research in the public sector
}

\section{Structured abstract}

Purpose: The purpose of this article is to review opportunities for future research about auditing in the public sector.

Design/methodology/approach: The article presents the viewpoints of two researchers, supported by research which is cited in the paper.

Findings: Public sector auditing research has grown considerably. We expect further growth. We debunk some myths about public sector auditing. We suggest areas where there are opportunities for research. In particular, researchers can examine a broader range of jurisdictions, investigate differences among countries, and develop suggestions about what works best.

Research limitations/implications: The paper presents the views of the authors.

Practical implications: There are opportunities for further research across different jurisdictions.

Originality/value: The paper makes a contribution by outlining research opportunities.

\section{Keywords}

Auditing, public sector, accounting, governmental, Supreme Audit Institutions 


\section{The future of auditing research in the public sector INTRODUCTION}

In this article we present our views, based on evidence, about the future of auditing in the public sector. This paper is based on research by David Hay and Carolyn Cordery, especially in the forthcoming book, Public Sector Auditing published by Routledge, and on a keynote speech by David Hay at the Comparative International Government Accounting Research (CIGAR) workshop in Oslo, Norway, conducted online in June 2020.

We both bring public sector and private sector experience to these projects. David Hay is the editor-in-chief of the International Journal of Auditing, and author of widely cited research papers, which are mainly in the private sector auditing research area. David also worked in the public sector area much earlier in his career, completing his PhD in public sector accounting, in the New Zealand setting. Before that he was a private sector auditor working for Price Waterhouse.

Carolyn Cordery is Joint Editor of Accounting History and her research focuses on not-for-profit organizations' accounting and accountability. Given the frequent outsourcing of public services to these organizations, it was a natural extension of her research to analyze public sector audit as a means of accountability. Much of her work is based on international comparisons. Prior to joining academia and completing her PhD, Carolyn worked in the private sector as a financial accountant and was a Member of the New Zealand Stock Exchange.

Working together, we have published three recent papers on public sector auditing and the forthcoming book (Cordery and Hay, 2019, 2021; Hay and Cordery, 2018, 2020).

"The future of auditing research in the public sector" is a very broad general topic. This paper does not aim to predict the future, but it provides some insight based on current trends. Auditing research has grown a lot over recent decades, and there is considerable potential for it to develop further, especially in the public sector. Our paper includes discussing public sector auditing in contrast to private sector auditing; our views about research and the potential for more research, especially in the public sector; and our views about what researchers should aim to do in future.

First, the paper presents an overview of the future of auditing. There is great potential for public sector auditing research. We also examine some issues that could be explored, and some data that we review in part of the forthcoming book. We also engage in some myth busting. We then look at how researchers in the public sector and private sector can learn from each other. We conclude by exploring what should be done next, by researchers and practitioners.

\section{THE GROWTH OF PUBLIC SECTOR AUDITNG RESEARCH}

To look at the potential for research, we reviewed how much research already exists in the private sector and the public sector. The count of scholarly articles 
according to a search of Google Scholar provides an approximate measure, shown in Table 1 . Auditing research of any kind is a comparatively new area.

\section{INSERT TABLE 1}

There was virtually no auditing research before 1980 . The table shows that our search indicated that there were a total of 16,100 articles identifiable as "auditing research"; of those, 14,500 (90\%) were published in the last twenty years since 2000 , and 5,300 (33\%) since 2016. The rapid growth since 2000 is probably because scandals, and the resulting reforms, made auditing more interesting. Partly as a result of the scandals, there was increased disclosure of audit data, and so there were also more opportunities for research.

In public sector auditing there were 1,779 articles in all, the vast majority since $2000(1,710$, or $99 \%)$. Of these, $733(41 \%)$ are published in 2016 or later. All of the trends in auditing research are more pronounced in the public sector. There were even fewer studies before 2000, the number of studies has grown more quickly since then and the number of papers since 2016 shows the area is still growing even faster.

Nevertheless the quantity of research is still very small, considering that public sector auditing takes place everywhere. Auditing of all central and decentralized government entities is a substantial part of the auditing that takes place in any economy. The public sector is a substantial proportion of those parts of the economy that are audited (excluding small entities, for example). The public sector affects the whole population; and it includes unique and interesting issues. ${ }^{1}$ There being so much public sector auditing, but so little research, provides opportunities. The research settings are diverse and there are important issues. There are opportunities.

Giuseppe Grossi and Giorgia Mattei have written a paper that looks at public sector auditing research more systematically, which is recommended (Grossi and Mattei, 2020). The paper followed this one on the program at the CIGAR Workshop.

As a result of the opportunities that exist, we expect there to be a lot of growth in public sector auditing research, and for that area of research to be a lot more influential. One reason for that is as part of the growth of evidence-based standard setting. It is clear that evidence-based standard setting is becoming more influential in a number of areas. The Australian Auditing and Assurance Standards Board (AUASB) has a policy on evidence-informed standard setting (Australian Auditing and Assurance Standards Board, 2020). The Dutch Authority for the Financial Markets recently released a report on auditing that was based on research (Dutch Authority for the Financial Markets, 2018). Other bodies are also showing increasing interest in evidence based standard setting, including the International Ethics Standards Board for Accountants (IESBA) (Hay, 2017) and the International Auditing and Assurance Standards Board (IAASB) (including for example the enhanced audit report that includes Key Audit Matters). The International Public Sector Accounting Standards Board (IPSASB) 
has increased its outreach to academics and there are more opportunities to engage with IPSASB (Jensen, 2020). Its Work Plan includes the word evidence (although not often) (IPSASB, 2019), and IPSASB's association with the CIGAR workshop is another positive sign.

There are other issues about public sector auditing research. One is the dichotomy between the alternative (contextual) and the mainstream bodies of public sector auditing research (Goddard, 2010). These two areas have tended to also represent qualitative versus quantitative research. We suggest a reason for that dichotomy. It may be that public sector auditing research was such a small area that researchers had to appeal to other audiences. To find those audiences, their work had to reach out either to other researchers in the mainstream of auditing research or to those in the critical perspectives literature. Being accessible to audiences for research in those areas is still very useful, but now there is more of a public sector community and there is less need to have public sector auditing research divided into two areas that do not link up well. There is potential for the two areas to complement each other in future research.

Another issue about public sector auditing research is the patchy coverage by existing studies. There is very unbalanced coverage of the range of countries and types of auditing included. There is more research about public sector auditing concerned with Australia and New Zealand than you might expect, for instance. There are bodies of research about the United Kingdom and the United States, but there are also many countries for which there is very little public sector auditing research.

\section{HOW PUBLIC SECTOR AUDITING VARIES AROUND THE WORLD}

Some questions for research, which are yet to be resolved, include the extent to which there are variations in public sector auditing around the world. When we discuss public sector auditing with government auditors, we often find that the subject matter that we are talking about in different countries appears to be the same, but, when looked at closely, the auditing activities carried on and the set of entities audited are quite different. This extent of variation occurs even between similar countries, such as Australia and New Zealand. Supreme Audit Institutions, for example, all seem to have their own unique features.

That seems to be a very interesting issue. The question of variations in public sector auditing - why do they exist, and what impact do they have? In the forthcoming book, we discuss questions such as, how important are SAIs? How different are they from each other? Why do these variations exist? What model, out of the various SAI models that are used, works best? We examine these questions with the application of theory.

There is a fascinating study of SAIs by Blume and Voigt (2011). It examines the organizational design of SAIs and their economic effect. It is an economics study. According to the paper, it "assesses the economic effects of differences in organizational design of supreme audit institutions (SAIs)". In that study, the impact of SAIs on the economy is measured. They consider whether there is a measurable impact of auditing on fiscal policy, on government effectiveness and 
corruption, and on productivity. The study relates measures for those issues to SAI characteristics. They report that "differences in the independence, the mandate, the implementation record, and the organizational model of the SAIs do not seem to have any clear-cut effect". They find one exception: "perceived levels of corruption are significantly higher if the SAI is structured along the court model of auditing." It seems very surprising to suggest that SAIs could have such a substantial effect that their impact would be noticeable on government effectiveness, or on productivity (and they do not find this effect). That the auditing model could have an impact on corruption is more plausible, and they do find a result.

That paper gives us a lead, demonstrating what might be possible in public sector auditing, but it has a lot of limitations. Do they have good data? Do they have enough data? And if there are variations, it is still useful to know why they occur. How does it come about that countries have different models of SAI?

In the forthcoming book by Cordery and Hay we look at more specific research questions. Specifically we look at what types of SAI there are; what determines the type of SAI; and what outcomes it has in areas such as corruption or standard of public sector accounting. Our study presents preliminary results only, without extending to multivariate tests.

We find it helpful to use neo-institutional theory in explaining those issues. Neoinstitutional theory examines the extent to which organizations are subject to isomorphism. In other words, why do organizations with similar functions come to look like each other? The theory is based on work by DiMaggio and Powell (1983). Isomorphism comes about because of three types of pressure: coercive, mimetic, and normative influences. Table 2 summarizes the theory.

\section{INSERT TABLE 2}

In brief, coercive isomorphism applies where there is a force applied by government or interactions with other organizations that makes organizations come to resemble other organizations in the same field. Coercive isomorphism is most likely to apply when there is dependence on another organization. In this setting that might be because there are loans, or aid, to the country concerned. Mimetic isomorphism takes place through entities copying successful or legitimate organizations. This process is most likely to take place when the organization operates in a setting where there are uncertain relationships between means and ends, or uncertain goals. The SAIs in some countries may be subject to more uncertainty than others, and may have other SAIs they can emulate as role models. Under the third explanation, normative isomorphism, organizations come to resemble each other through professionalism that managers pick up from their education, or from their professional networks. It is most likely to occur in organizations in which managers actively participate in professional organizations. Public sector auditing has strong professional organizations like INTOSAI and the regional SAI bodies, and perhaps these are an influence on the organizational form of SAIs. We applied these potential explanations to our observations. 
We used data from the INTOSAI database maintained by the SAI of Mexico, which they very generously made available to us. We also used data from the World Bank and other public sources; and we conducted our own survey of SAIs. A big issue with any study of this kind is the completeness of the data. Like other studies, we have issues with data completeness.

There are some useful findings. We found that SAIs use a wide range of SAI model classifications for themselves, often including more than one type. While it is customary in the research literature to classify SAIs into one of three or four models, this is a simplification of the complex reality (even if it is useful). While we expect institutions to classify themselves as using the Westminster model, the court model or the board model, there is much more variation, and many countries classify themselves as using more than one model, or something completely unique. If a simplified classification is needed, the court model versus others is the most useful classification (because it seems to be associated with other differences and is useful for explaining them).

The SAIs are each unique in other ways, including for example which entities are covered. In some countries, all public sector entities including very small local authorities and state owned enterprises are the responsibility of the SAI, while in others the SAI looks after only federal government departments; in some countries the SAI's responsibility extends to political parties, or to churches or other private bodies that receive government funding (e.g. NGOs). SAIs also vary considerably in size, and in the type of auditing that they do (compliance, financial or performance auditing).

Our results, when we applied neo-institutional theory to the simple descriptive statistics that we report in Public Sector Audit (2021) are mixed, but with some support for the explanations that we considered. We looked first at coercive isomorphism. That explanation is not supported by the evidence. International aid received, levels of debt or the size of the stock market are not related to choice of a model. While there is anecdotal evidence, particularly that aid providers or lenders sometimes exert their influence regarding accounting or auditing, that effect does not show up in the overall statistics.

Mimetic isomorphism, on the other hand is supported by evidence. The results indicate that the stability of a country, and the extent to which there is rule of law are associated with the Westminster model of SAI. The Westminster model is widely used by stable countries and appears to be emulated by those that are less stable.

There is consistent evidence to support normative isomorphism. The strength of professional accounting and the level of education in a country are associated with use of the Westminster and board models. Membership of a regional SAI group is also influential. We found that countries in regional SAI groups tended to coalesce around a particular model.

The evidence allowed us to do some 'myth busting'. We examined some common beliefs, and assessed whether they are indeed supported by evidence. First. it is often suggested that SAIs can be classified into a small number of 
categories (Bonollo, 2019; Pollitt and Summa, 1997; Reichborn-Kjennerud et al., 2019; Stapenhurst and Titsworth, 2001).

So myth number one is: "There are three (or four) SAI models". Our results show that is not the case. SAIs are much more diverse, and when they describe themselves (as they do in the INTOSAI database) they are much more likely to use a combination of models and some unique descriptions. Nevertheless, the standard models have some element of realism, and are still useful - especially the distinction between the court model and others.

Second, it is sometimes asserted that SAI models are determined by history, especially colonisation (e.g., Heald, 2018). This is not as much the case as might be expected. We found that, especially, the Westminster model is widely used by countries which do not have a history of being colonized by the British Empire as well as by those that were.

Third, it is argued that "the court model is the least effective" (Blume and Voigt, 2011; Johnsen, 2019). The evidence does show a correlation between use of the court model and increased corruption - but evidence that the court model is the cause of the corruption is not as clear. We suggest that it can be argued that the court model is the most suitable for countries that are large and where corruption is an issue. While the Westminster model is widely used, it is often (but not always) associated with smaller countries. Large countries with a historic issue of corruption tend to use the court model. This association leads to the conclusion in Blume and Voigt (2011) that the court model is the least effective - but we do not know what would happen if these countries switched to a Westminster or board model, and there is no evidence that this would make them less corrupt. We argue that all of those common beliefs (three SAI models, determination by history, and the weakness of the court model) are not supported by evidence. DISCUSSION

Overall, our research can be summarized as showing results that are consistent with some but not all expectations. There is considerable potential for more detailed research examining all of the issues discussed so far in this paper.

The next part of this discussion is about learning. What can we learn from the changing world of auditing, with its recent auditing scandals and general feeling that auditing is in crisis? First, we consider what it is that private sector auditing can learn from the public sector. The background, especially in certain countries like the UK, Australia or South Africa, is of widely-publicized scandals in auditing, generally in the private sector, and an expectation gap that is hard to reduce. This background has led to many recent reports about auditing and what can be done to improve it (Brydon, 2019; Dutch Authority for the Financial Markets, 2018; Independent Regulatory Board for Auditors, 2019; Parliamentary Joint Committee on Corporations and Financial Services, 2020). There is a wave of change, or at least discussion about change, taking place. Perhaps the private sector could learn more from public sector auditing. In some countries, there is much more transparency of public sector auditing than there is in the private sector, through reporting and through blogs and social media (Hay and Cordery, 2020). In some countries, armchair auditors have been effective (O'Leary, 2015; 
Susskind and Susskind, 2015). Use of armchair auditors as a form of 'bottom-up' accountability making use of citizens appears to have been important to government when recent reforms were enacted in the United Kingdom (Ferry et al., 2015; Ferry and Eckersley, 2015) In addition, the lack of competition among SAIs means that they are free to develop new responses to audit demands (e.g. auditing of progress towards the UN SDGs) through the INTOSAI.

And what can public sector auditing learn from the private sector? There are some private sector practices that public sector entities and their auditors could learn from. After the auditing scandals of about twenty years ago, large American listed companies were required to report on their internal control, and their auditors were required to provide assurance over internal control, under the Sarbanes-Oxley Act. While this reform was not popular at first, it is now well-established and widely regarded as successful (Bedard and Graham, 2014). Auditors provide an opinion on internal control, draw attention to weaknesses, and highlight weaknesses reported in the previous year that management have not remediated. Similar levels of assurance or transparency over internal control are not always provided in the public sector. Yet internal control reporting could be even more relevant as a control over entities that spend public money.

Another area concerns the links between governance and auditing. The private sector appears to be better at making links between audit committees and external auditing, although recent reports in the UK suggest improvements in this area (Ferry, 2019; Redmond, 2020). Including Key Audit Matters (KAMs) in the audit report (Critical Audit Matters in the USA) is another private sector innovation that is likely to be useful in the public sector. And finally, private sector auditors around the world are generally under the oversight of an independent oversight body (Offermans and Vanstraelen, 2014). Some SAIs have also made themselves subject to inspection (Cordery and Hay, 2019), but this additional control over the quality of auditing could be more widely used in the public sector.

To conclude, what can public sector auditing researchers do now? There are opportunities, especially as standard setting bodies are now becoming more aware of the benefits of evidence based standard setting that makes use of research findings. It may be that the dichotomy between the mainstream and the alternative streams of research is no longer necessary and will fade away. There are opportunities to further develop research - for example covering a broader range of countries, or looking into why SAIs are the way they are; and into what works best in public sector auditing. Evidence from neo-institutional theory appears to suggest support from normative isomorphism and possibly mimetic isomorphism, but apparently not for coercive isomorphism. However, this issue still needs further investigation. An issue for researchers is to do this research in a way that is generalizable, perhaps using a very high-quality singlecountry public sector auditing study, that is not too specific to that particular setting to be relevant for the wider community. Alternatively, studies that compare and contrast different practices in different settings are likely to be very illuminating, and more likely to be publishable. There are also opportunities to further develop auditing practices. Public sector auditors can learn from current 
recommendations for reform of private sector auditing, and in the areas of governance, and independent inspection of auditors. Private sector auditors can learn from the transparency of public sector auditors.

The future of auditing research in the public sector has considerable potential. There is potential for useful and publishable research, and potential to contribute to practical improvements. 
References

Australian Auditing and Assurance Standards Board. (2020), AUASB EvidenceInformed Standard Setting Strategy, Melbourne.

Bedard, J.C. and Graham, L. (2014), "Reporting on internal control", in Hay, D., Knechel, R. and Willekens, M. (Eds.), The Routledge Companion to Auditing, Routldege, Abingdon, UK, pp. 311-322.

Blume, L. and Voigt, S. (2011), "Does organizational design of supreme audit institutions matter? A cross-country assessment", European Journal of Political Economy, Elsevier B.V., Vol. 27 No. 2, pp. 215-229.

Bonollo, E. (2019), "Measuring supreme audit institutions' outcomes: current literature and future insights", Public Money \& Management, Taylor \& Francis, Vol. 39 No. 7, pp. 468-477.

Brydon, D. (2019), Assess, Assure and Inform: Improving Audit Quality and Effectiveness: Report of the Independent Review into the Quality and Effectiveness of Audit, London, available at: https://assets.publishing.service.gov.uk/government/uploads/system/uploa ds/attachment_data/file/852960/brydon-review-final-report.pdf.

Cordery, C.J. and Hay, D.C. (2019), "Supreme audit institutions and public value: Demonstrating relevance", Financial Accountability \& Management, Vol. 35 No. 2, pp. 128-142.

Cordery, C.J. and Hay, D.C. (2021), Public Sector Audit, Routledge, Abingdon, Oxford.

DiMaggio, P.J. and Powell, W.W. (1983), "The Iron Cage Revisited: Institutional Isomorphism and Collective Rationality in Organizational Fields", American Sociological Review, Vol. 48 No. 2, pp. 147-160.

Dutch Authority for the Financial Markets. (2018), Vulnerabilities in the Structure of the Audit Sector, Amsterdam, available at:

https://www.afm.nl/en/nieuws/2018/nov/kwetsbaarheden-structuuraccountancysector.

Ferry, L. (2019), Audit and Inspection of Local Authorities in England: Five Years after the Local Audit and Accountability Act 2014, London, available at: https://www.parliament.uk/globalassets/documents/commonscommittees/communities-and-local-government/Correspondence/Ferrylocal-authorities-audit-report.pdf.

Ferry, L. and Eckersley, P. (2015), "Budgeting and governing for deficit reduction in the UK public sector: act three 'accountability and audit arrangements'", Public Money \& Management, Vol. 35 No. 3, pp. 203-210.

Ferry, L., Eckersley, P. and Zakaria, Z. (2015), "Accountability and Transparency in English Local Government: Moving from ' Matching Parts ' to ' Awkward Couple '?", Financial Accountability \& Management, Vol. 31 No. 3, pp. 345361.

Goddard, A.R. (2010), "Contemporary public sector accounting research - An international comparison of journal papers", The British Accounting Review, Elsevier Ltd, Vol. 42 No. 2, pp. 75-87. 
Grossi, G. and Mattei, G. (2020), "Exploring Past and Future Trends In The Public Sector Audit A Literature Review", CIGAR Workshop 2020, Oslo, pp. $1-31$.

Hay, D.C. (2017), "Audit Fee Research on Issues Related to Ethics", Current Issues in Auditing, Vol. 11 No. 2, pp. A1-A22.

Hay, D.C. and Cordery, C.J. (2018), "The value of public sector audit: Literature and history", Journal of Accounting Literature, Vol. 40, pp. 1-15.

Hay, D.C. and Cordery, C.J. (2020), "Evidence about the value of financial statement audit in the public sector", Public Money \& Management, Taylor \& Francis, Vol. 0 No. 0, pp. 1-11.

Heald, D. (2018), "Transparency-generated trust: The problematic theorization of public audit", Financial Accountability \& Management, pp. 1-19.

Independent Regulatory Board for Auditors. (2019), Public Inspections Report 2019, Modderfontein.

IPSASB. (2019), Strategy and Work Plan 2019-2023. Delivering Global Standards. Inspiring Implementation.

Jensen, G. (2020), "The IPSASB's recent strategies: opportunities for academics and standard-setters", Journal of Public Budgeting, Accounting and Financial Management, available at:https://doi.org/10.1108/JPBAFM-04-2020-0050.

Johnsen, $\AA$. (2019), "Public sector audit in contemporary society: A short review and introduction", Financial Accountability \& Management, Vol. 35 No. 2, pp. $121-127$.

O'Leary, D.E. (2015), "Armchair Auditors: Crowdsourcing Analysis of Government Expenditures", Journal of Emerging Technologies in Accounting, Vol. 12 No. 1, pp. 71-91.

Offermans, M. and Vanstraelen, A. (2014), "Oversight and inspection of auditing", in Hay, D.C., Knechel, W.R. and Willekens, M. (Eds.), The Routledge Companion to Auditing, Routledge, Abingdon, Oxon, UK, pp. 179188.

Parliamentary Joint Committee on Corporations and Financial Services. (2020), Regulation of Auditing in Australia: Interim Report, Canberra, available at: https://parlinfo.aph.gov.au/parlInfo/download/committees/reportjnt/024330 /toc_pdf/RegulationofAuditinginAustralia.pdf;fileType=application\%2Fpdf.

Pollitt, C. and Summa, H. (1997), "Comparative and International Administration Reflexive Watchdogs? How Supreme Audit Institutions Account for Themselves", Public Administration, Vol. 75, pp. 313-336.

Redmond, S.T. (2020), Independent Review into the Oversight of Local Audit and the Transparency of Local Authority Financial Reporting, London, available at:

https://assets.publishing.service.gov.uk/government/uploads/system/uploa ds/attachment_data/file/916217/Redmond_Review.pdf.

Reichborn-Kjennerud, K., González-Díaz, B., Bracci, E., Carrington, T., Hathaway, J., Jeppesen, K.K. and Steccolini, I. (2019), "Sais work against 
corruption in Scandinavian, South-European and African countries: An institutional analysis", The British Accounting Review, Vol. 51, p. 100842.

Stapenhurst, R. and Titsworth, J. (2001), Features and Functions of Supreme Audit Institutions, World Bank PREM-Notes, available at:

https://openknowledge.worldbank.org/handle/10986/9766.

Susskind, R. and Susskind, D. (2015), The Future of the Professions, ebook., Oxford University Press, Oxford. 
${ }^{1}$ One possible explanation for the concentration of research on the private sector is the influence of teaching at universities. There is high demand for auditing graduates to join audit firms, so that university courses tend to be focused in that direction, and the professors who teach the courses also tend to be interested in private sector issues and to focus their research in that direction. This is reinforced by other business research that tends to be focused on private enterprise too, perhaps because of the influence of economists in business schools and their interest in markets. 